\title{
China's Urban GHG Inventory and Emissions
}

\author{
Chaolin GU1, Yan $\mathrm{LI}^{2}$ and lan G. COOK ${ }^{3}$
}

${ }^{1}$ Department of Urban Planning, School of Architecture, Tsinghua University, Beijing, P.R. China

${ }^{2}$ Graduate School, Ritsumeikan Asia Pacific University, Japan

${ }^{3}$ School of Humanities and Social Science, Liverpool John Moores University, UK

*Corresponding author: Chaolin GU, Department of Urban Planning, School of Architecture, Tsinghua University, Beijing, 100084, P.R. China, Tel: +86 10 6279 3001 ; E-mail: gucl@tsinghua.edu.cn

Received date: Aug 12, 2014, Accepted date: Oct 07, 2014, Published date: Oct 09, 2014

Copyright: @ 2014 Chaolin GU, et al. This is an open-access article distributed under the terms of the Creative Commons Attribution License, which permits unrestricted use, distribution, and reproduction in any medium, provided the original author and source are credited.

\begin{abstract}
China is now experiencing dramatic urbanization, the environmental impact of which is a global concern. This paper focuses on city-level GHG (Greenhouse Gas) inventory and emission in the metropolitan areas. Firstly, the paper introduces various inventory methods especially three key models that have been used to develop a GHG inventory: the emission-oriented IPCC and WRI/WBCSD GHG emission model, the demand-oriented mixed lifecycle method, and the ICLEI GHG inventory method. Secondly, the paper introduces the progress of the national and provincial GHG inventory and provides an overview of key research results related to development of individual city's inventories in China. Thirdly, in order to examine the progress of the urban GHG inventory in China, the paper takes Beijing as an example to review the relevant research. Beijing's $\mathrm{GHG}$ studies are mainly focused on $\mathrm{CO}_{2}$ emissions, without considering other GHGs required by the IPCC reporting. According to current publications, most research on Chinese urban GHG inventory fails to meet the method of IPCC. It is difficult for Chinese researchers to achieve statistical requirements of the ICLEI protocol on two levels and three scopes or the Global Protocol. Therefore, it is very important that cities in China establish a GHG inventory framework and methodology system that effectively addresses climate change and permits international comparisons as well.
\end{abstract}

Keywords: Urban GHG Inventory; $\mathrm{CO}_{2}$ Emissions; China; Beijing

\section{Introduction}

By 2010 , urban areas contained more than $50 \%$ of the world's population, consumed $75 \%$ of the world's energy resources, and took up $80 \%$ of greenhouse gas (GHG) emissions from global human activities [1]. As population increases and the urbanization process speeds up, the issue of global GHG emissions will become more and more severe. GHG emissions have been both the focus of global attention and a hot spot of research. China, as the most populated country in the world, is accelerating its urbanization process. In 2013, the Chinese urbanization level reached $53.73 \%$ with a population of 20 million added into cities each year. China is also undertaking an important international obligation and plays an increasingly essential role in addressing global climate change and reducing GHG emissions. This paper analyzes the progress of the urban GHG inventory and emissions in China, with particular reference to Beijing.

\section{Urban GHG Inventory Methods}

There are many calculation methods of greenhouse gas (GHG) [2] emissions based on nations, cities, buildings, corporations, products and production processes, and so on. We can divide these methods into two categories. The first has geographic boundaries, such as IPCC Guidelines for National GHG Inventories (IPCC, 1996), ICLEL local GHG Inventories (ICLEL, 2009b) and GRIP regional GHG inventory Protocol [3]. China's Guidelines for provincial-level GHG Protocol [4] belongs to this category. The second is concerned with the organization's operational boundaries, such as The GHG Protocol: A Corporate Accounting and Reporting Standard [5], Series of ISO 14064 standards [6] Guide PAS2050 and standard PAS2060 (Table 1). We also can divide the GHG inventory into two kinds of scopes: production and consumption (Table 1). The production pattern calculates the total GHG emissions due to goods and service productions within a geographical boundary, regardless of the location where the goods or service are consumed; the consumption pattern only counts the GHG emissions based on the goods or service that people within a boundary or an organization consume.

There are three key models that may be used to develop an Urban GHG Inventory, as follows:

\section{Emission-oriented IPCC and WRI/WBCSD GHG emission model}

Inventory methods at the urban level generally determine the GHG emission model based on the International Climate Framework Convention of Nations [7] and Enterprises (WRI/WBCSD 2009).

\section{Demand-oriented mixed lifecycle method}

Ramaswami et al. [8] and Kennedy et al. [9] developed an urbanscale GHG inventory oriented in demand and based on mixed lifecycle: (1) the amount of emissions of surface space of metropolis region and air travels between peer cities; (2) Lifecycle Assessment, the amount of emissions of urban main quantifiable substantial supply food, water, fuel, energy and concrete. 


\begin{tabular}{|c|c|c|c|c|c|}
\hline Methods & Purpose & Preparation & Type of boundaries & Scope & Agency \\
\hline $\begin{array}{l}\text { IPCC Guidelines for National } \\
\text { GHG Inventories }\end{array}$ & $\begin{array}{l}\text { GHG inventories in different countries } \\
\text { and regions to provide accounting } \\
\text { framework and approach }\end{array}$ & $\begin{array}{l}\text { Countries and } \\
\text { regions }\end{array}$ & $\begin{array}{l}\text { Geographical } \\
\text { boundaries }\end{array}$ & Production & IPCC \\
\hline ICLEL City GHG Inventories & $\begin{array}{l}\text { To find major sources of GHG emissions } \\
\text { in urban areas }\end{array}$ & Cities & $\begin{array}{l}\text { Geographical } \\
\text { boundaries }\end{array}$ & $\begin{array}{l}\text { Production } \\
\text { consumption }\end{array}$ & ICLEL \\
\hline $\begin{array}{l}\text { GHG Regional Inventory } \\
\text { Protocol, (GRIP) }\end{array}$ & $\begin{array}{l}\text { Statistical monitoring of GHG emissions } \\
\text { in order to compare to the potential } \\
\text { emissions reductions between the cities }\end{array}$ & Cities & $\begin{array}{l}\text { Geographical } \\
\text { boundaries }\end{array}$ & $\begin{array}{l}\text { Production } \\
\text { consumption }\end{array}$ & $\begin{array}{l}\text { University of } \\
\text { Manchester }\end{array}$ \\
\hline $\begin{array}{l}\text { China Provincial } \quad \text { GHG } \\
\text { Inventory Protocol }\end{array}$ & $\begin{array}{l}\text { To find out the status of provincial GHG } \\
\text { emissions in order to implement long- } \\
\text { term plan to control GHG emissions }\end{array}$ & Provinces & $\begin{array}{l}\text { Geographical } \\
\text { boundaries }\end{array}$ & Production & China's NDRC \\
\hline $\begin{array}{l}\text { The GHG Protocol: } \mathrm{A} \\
\text { Corporate Accounting and } \\
\text { Reporting Standard }\end{array}$ & $\begin{array}{l}\text { Accounting corporate GHG emissions } \\
\text { and } \mathrm{GHG} \text { action plan on the basis of } \\
\text { business enterprises, trade }\end{array}$ & Enterprises & $\begin{array}{l}\text { Organizations } \\
\text { operating boundaries }\end{array}$ & $\begin{array}{l}\text { Production } \\
\text { consumption }\end{array}$ & WRI/WBCSD \\
\hline Series of ISO 14064 standards & To emphasize on ISO standards & $\begin{array}{l}\text { Corporate, } \\
\text { business } \\
\text { projects, }\end{array}$ & $\begin{array}{l}\text { Organizations } \\
\text { operating boundaries }\end{array}$ & $\begin{array}{l}\text { Production } \\
\text { consumption }\end{array}$ & ISO standards \\
\hline Guide PAS2050 & $\begin{array}{l}\text { Accounting of full life cycle of a product } \\
\text { or service consumer }\end{array}$ & $\begin{array}{l}\text { Products, } \\
\text { services }\end{array}$ & $\begin{array}{l}\text { Organizations } \\
\text { operating boundaries }\end{array}$ & $\begin{array}{l}\text { Production } \\
\text { consumption }\end{array}$ & $\begin{array}{l}\text { British Standards } \\
\text { Institute }\end{array}$ \\
\hline Standard PAS2060 & $\begin{array}{l}\text { Reducing compensation to implement a } \\
\text { carbon neutral }\end{array}$ & $\begin{array}{l}\text { Countries, } \\
\text { communities, } \\
\text { companies, } \\
\text { individ }\end{array}$ & $\begin{array}{l}\text { Organizations } \\
\text { operating boundaries }\end{array}$ & $\begin{array}{l}\text { Production } \\
\text { consumption }\end{array}$ & $\begin{array}{l}\text { British Standards } \\
\text { Institute }\end{array}$ \\
\hline
\end{tabular}

Table 1: Types of GHG inventory methods.

This mixed method will separately report the GHG emitted directly from terminal use of energy (comprising Environmental Protection Agency (EPA) methods and IPCC methods), and the extra crossborder effects such as emission amount from air travel and main substantial production in the city (Scope 3 suggested by the World Resource Institute). The mixed method has been applied to Denver, State of Colorado, and generated a more comprehensive GHG inventory which is identical to the result of GHG trace calculation.

\section{ICLEI GHG inventory method}

The International Council for Local Environmental Initiatives [10] classifies GHG inventory into two levels: government and community. The degree of complexity with respect to emissions calculations depends on many factors, including scale, a function of the number of actors and geographies involved, as well as data availability and accuracy; and scope of the estimate: Scope I for direct emissions; II, which includes indirect emissions from purchased electricity; and III, that includes emissions associated with the production of purchased materials, product use, outsourced activities, contractor owned vehicles, waste disposal, and employee business travel among others.

Therefore, by viewing the GHG emissions of a city, we can view the city as a demand center of energy and material rather than being concerned only with how much has been emitted within the city. The GHG inventory at the urban level includes direct and indirect emission inventory separately. The demand-oriented mixed life-cycle GHG inventory methods mainly include three classifications: (1) direct energy consumption in buildings and facilities (terminal use), including housing, commercial, industrial and governmental buildings and facilities; (2) transportation-related direct (tailpipe) emissions associated with transportation, including surface and air travel, with a unique spatial allocation procedure applied to allocate such travel within and across city boundaries (3) indirect emission involving embodied energy of the city's main substantial energy and household waste (e.g. landfills). According to the basic functions of the city, the main substances of the city include food, water, fuels and concrete (dominating building materials). Demand-oriented mixed life-cycle method is oriented by demand, which includes a mixed GHG inventory method of urban direct GHG emissions related to terminal energy use and indirect GHG emission amount related to main substances that supported the city. The emissions inventory of direct terminal use complies with the IPCC. ICLEI's revised inventory protocol closely follows WRI/WBCSD's method, but does not explicitly define the relevant Scope 3 activities. More recently, the ICLEI has become one of the three partners in the emergence of the Global Protocol, along with the C40 Cities Climate Change Leadership Group and the World Resource Institute [10] and is expected to be the international standard, but for China in general, and Beijing in particular, this approach is still in its infancy.

\section{Urban GHG inventory in China}

China has 30 provinces as its second level administrative boundaries, while cities are the sub-regions of the province. Development of urban GHG inventories may directly be influenced by the provincial or national inventory. Some research results of four Municipalities directly under the central government, namely Beijing, Shanghai, Tianjin and Chongqin, are related to development of the individual city's inventory. 


\section{China's national and provincial GHG inventory}

According to the requirements of the United Nations Framework Convention on Climate Change (UNFCCC), all countries will submit national information notification, including an Emissions Inventory. China is one of the first contracting parties of the UNFCCC. As a developing country, China belongs to non-Annex I parties which do not have to undertake the obligation of emission reduction, but have to submit national information notification. The core element of national information notification is the national inventory of source and sink of three GHGs: $\mathrm{CO}_{2}, \mathrm{CH}_{4}$ and $\mathrm{N}_{2} \mathrm{O}$, and the measures taken or to be taken to honor the agreement. Lin [11] was among the earliest publications about preparation of China's GHG inventory.

In 2004, China published the National Information Notification, in which China preliminarily calculated the amount of $\mathrm{CO}_{2}$ emission of China in 1994. Actually, until recently, although analysts have been discussing the GHG emissions, China lacks exact $\mathrm{CO}_{2}$ statistical data. China national level GHG inventory had been completed according to the IPCC Guidelines for National GHG Inventories in 1994 and 2005.

In 2010, China launched the Second National Information Notification, including an emissions inventory. According to the requirements in the UNFCCC, China's second National Information Notification will not only calculate carbon dioxide $\left(\mathrm{CO}_{2}\right)$, nitrous oxide $\left(\mathrm{N}_{2} \mathrm{O}\right)$ and methane, but also three other GHGs: hydrofluoric acid (HFC), PFC and $\mathrm{SF}_{6}$. And it will cover Hong Kong and Macau for the first time. It is predicted to be finished in 2013 .

In March 2010, “China's Preparation for Second National Information Notification Construction" program put forward five sub-programs Preparation of GHG Inventory from Energy Activities, Preparation of GHG Inventory from Farmland, Preparation of GHG Inventory from Land Use Change and Forestry, Building China's GHG Emissions inventory Database and China's GHG Emission Forecast Methods. The Department of Climate of the State Development and Reform Commission held a discussion forum about "China's GHG Emission Forecast Methods" program progress in June 2010, and also a "Preparation of GHG Inventory from Energy Activities" discussion forum in August and a "Preparation of GHG Emissions inventory from Industrial Production Process" in September.

Geng et al. [12] estimates $\mathrm{CO}_{2}$ emission inventories from energy consumption and carbon intensities of provinces and municipalities in Mainland China in 1990, 1995, 2000, and 2005-2008 using the IPCC mass balance approach. In 2012, China stated that its energy consumption was $2735.3 \mathrm{Mt}$ and carbon emissions have reached 9208.1 Mt $\mathrm{CO}_{2}$, accounting for $21.9 \%$ and $26.7 \%$ respectively of the world total [13] and reached 6.82 tons of carbon emissions per capita $\mathrm{CO}_{2} /$ person, more than the world average of $4.89 \mathrm{t} \mathrm{CO}_{2} /$ person (Table 2).

At the provincial level, China also made every effort in this work. In 2005, The Provincial Level GHG Inventory Preparation Guidelines (Trial), which were based on IPCC Guidelines for National GHG Inventories and were combined with the experience of the work on the national GHG inventory, issued for guiding the preparation of lowcarbon [14] pilot provinces GHG inventories.

\begin{tabular}{|l|l|l|l|l|l|}
\hline Country/Regions & $\begin{array}{l}\text { Carbon emissions (Mt } \\
\left.\mathbf{C O}_{2}\right)\end{array}$ & $\begin{array}{l}\text { energy consumption } \\
(\mathrm{Mtoe})\end{array}$ & $\begin{array}{l}\text { Per capita carbon } \\
\text { emissions } \\
\text { person) }\end{array}$ & $\begin{array}{l}\text { Carbon productivity } \\
\left(\$ \mathbf{T} / \text { enen } \mathbf{C O}_{2}\right)\end{array}$ & $\begin{array}{l}\text { engy carbon emission } \\
\text { factor }\left(\mathbf{t} \mathbf{C O}_{2} / \text { toe }\right)\end{array}$ \\
\hline China & 9208.1 & 2735.2 & 6.82 & 893.46 & 3.367 \\
\hline U.S.A. & 5786.1 & 2208.8 & 18.43 & 2710.77 & 2.620 \\
\hline Japan & 1409 & 478.2 & 11.05 & 4229.75 & 2.946 \\
\hline EU & 3977.5 & 1673.4 & 7.88 & 4187.01 & 2.377 \\
\hline India & 1823.2 & 563.5 & 1.47 & 1010.16 & 3.235 \\
\hline World & 34466.1 & 12476.6 & 4.89 & 2079.33 & 2.762 \\
\hline
\end{tabular}

Table 2: Global energy consumption and carbon emission in 2010

In 2008, the State Development and Reform Commission started China's provincial climate change project, whose basic task is to require every province (autonomous regions, municipalities) to calculate GHG emissions. For this task China lunched the Provincial GHG Inventory Protocol. However, this has occurred without any city-level GHG inventories in China, except provincial level municipalities such as Beijing, Shanghai, Tianjin and Chongqin up until now.

\section{Carbon emissions related with urbanization in China}

Global $\mathrm{CO}_{2}$ emissions from the energy sector using data sets of power plants and motor vehicles, as well as estimates of fossil fuel emissions produced directly by industry, households, businesses, and other forms of transport [15]. In China, economy from 10.9655 trillion
RMB Yuan soared to 56.8845 trillion RMB Yuan, the level of urbanization from $37.7 \%$ to $52.3 \%$ between 2001-2013. Infrastructure inertia is greatest in China, where rapid economic development and industrialization in the past decade have led to a prodigious expansion of energy Infrastructure. Nearly $1 / 4$ of electrical generating capacity commissioned worldwide since 2000 is in coal-burning plants in China $(322.3 \mathrm{GW})$ [15]. Expansion of fossil infrastructure commonly project cumulative emissions from China's primary energy sector. China's primary energy consumption accounted for $11.0 \%$ of the world in 2001 to $21.3 \%$ in 2011 [13]. China alone accounts for roughly $27 \%$ of the global $\mathrm{CO}_{2}$ emissions.

Some of them such as industrial, residential and commercial infrastructure that burns fossil fuels represent a considerable commitment to future emissions. Non-energy emissions, of those 
unrelated to the combustion of fossil fuels, occur as the result of industrial processes such as the manufacture of cements and steel, where the chemical transformation of feedstock's releases $\mathrm{CO}_{2}$. China's industrial energy consumption has been from 1.595 billion tons of standard coal in 2005 to 2.4 billion in 2010, which accounted for about $73 \%$ of the China energy consumption. Six large high energy consumption industries such as iron and steel, nonferrous metals, building materials, petrochemical, chemical and power accounted for the proportion of total industrial energy consumption from $71.3 \%$ to about $77 \%$. Currently per capita living area of urban residents is $32.7 \mathrm{M}^{2}$, about half of the United States. Quick urbanization will use more steel and cements because the construction of one million M2 building of urban areas need to consume about 8.1 million tons of steel, 22 million tons of cement and 2.4 million M3 timber. China's road density is only $0.4 \mathrm{~km} / \mathrm{km}^{2}$, per capita road length of road also is less than $3 \mathrm{~m}$, about $40 \%$ and $50 \%$ in developed countries. China's per capita railway is only $0.06 \mathrm{~m}$, less than $6.9 \mathrm{~m}$ of the United States and $1.6 \mathrm{~m}$ of Japan. Chinese cities will increase energy demand of 2.8 billion tons of standard coal in 2010 to 3.6-4.0 billion tons in 2020, urban per capita energy consumption will be from 4.1 tons of standard coal in 2010 to $4.3-4.8$ tons in 2020. Chinese steel, cement, glass, ammonia and other major energy-intensive products will reach a peak in 2020-30.

The global transport sector also represents the next largest share of annual $\mathrm{CO}_{2}$ emissions (22.9\% in 2007) [16], of the total transportrelated emissions, nearly two-thirds is from road transport (74 Gt $\mathrm{CO}_{2}$ ) [15]. The proportion of China's oil consumption from transportation, storage and postal industry is about 34\% (Table 3). According to the Release of People's Republic of China on Climate Change second national communications (2004), $\mathrm{CO}_{2}$ emissions from transport energy activities (only mobile sources) was about 415.74 million tons, accounting for $7.5 \%$ of the total emissions. 2010 China accounted for energy and transport sectors account for carbon emissions such as Table 3. Surging vehicles sales in China 1990-2007 reflect growth of private vehicles ownership at a rate of $20 \%$ per year [17]. Chinese family car had an average capacity of 18.58 every 100 urban households, the lowest income households accounting for $10 \%$ of the total number of cities and towns was only 1.96 in 2011. It is clear that the oil consumption from transportation will be rise quickly in the near future.

\begin{tabular}{|l|l|l|}
\hline & Energy\% & carbon emissions\% \\
\hline Highway & 59 & 49.0 \\
\hline Railway & 7 & 4.0 \\
\hline Waterway & 24 & 35.0 \\
\hline Civil Aviation & 10 & 12.0 \\
\hline
\end{tabular}

Table 3: China transport energy consumption and carbon emissions (2010)

No doubt, Chinese cities have been and will be the main resources of the GHG emissions. China's huge scale of urbanization means that more GHG emissions in the future world. For this reason, research on methods, emission factors and characteristics of GHG emissions in urban China will help the government set reduction goals, draw up and carry out action plans, put forward practical and effective GHG emission reduction measures and lay a solid scientific foundation for cities for negotiation and communication on climate change and GHG problems internationally.

\section{Urban GHG Inventory and methods in China}

Research on urban GHG emission in China has only just begun. From the existing literature, China's national level inventory is too rough to use $\mathrm{CO}_{2}$ emission on the city level, and even where some cities have published results, the specific methods have not been described much. Xing [18] based his analysis on statistical data, according to the IPCC guideline method for estimating Beijing final energy carbon emissions between 1995-2005. In 2009, Zhu published "Research on Current Situations of Beijing's GHG Emissions and Emission Reduction Countermeasures" in China Soft Science [19]. Chen et al. [20] reviewed the research of urban greenhouse gas emission inventories.

Zhang and Yang [21] also estimated Shanghai $2008 \mathrm{CO}_{2}$ emissions inventory using the IPCC guideline method, of which coal accounted for $54 \%$ of $\mathrm{CO} 2$ emissions and petroleum use $32 \%$ of $\mathrm{CO}_{2}$ emissions. Zhao [22] show more than 90\% energy activities in GHG emissions in
Shanghai from 1996 to 2008 based on the IPCC method. Geng [23] portrayed four megacities of Beijing, Shanghai, Tianjin, Chongqing as the major source of $\mathrm{CO}_{2}$ emissions with one billion tons of carbon emissions, accounting for $10.8 \%$ coal-based energy consumption by IPCC methods in 1990, 1995 and 2004-2007. Wang et al. [1] estimated Wuxi City GHG emissions into the industrial, transportation, living, commercial, industrial processes and waste treatment by ICLEI method, and displayed the largest proportion of GHG from industry, energy, industrial processes and transport. $\mathrm{Xu}$ [24] shows that Nanjing's GHG emissions generated by energy consumption accounts for $69 \%$ of all emissions by the same methodology. Li et al. [25] reported their preliminary research on industrial carbon emissions in Kunming City.

Yang et al. [26] made a carbon emissions inventory by the energy, industry, waste treatment, agribusiness and animal husbandry, wetlands and forestry carbon sequestration process. Gu et al. [27] researched on carbon emissions from industry, transport, construction, agriculture of the four areas which refer to methods from the IPCC GHG inventory and the ICLEI urban inventory, and found that the industry is the largest source of carbon emissions in Harbin, with $76 \%$ of the total emissions from manufacturing and construction industry, energy, waste treatment. Ranked second were those from non-industrial emissions of carbon, including commercial buildings and residential buildings, about $14 \%$ of total emissions. Traffic carbon was listed as the third source of emissions, accounting for $9 \%$. Carbon emissions from agriculture were extremely weak, accounting for only $1 \%$ (Table 4 ). 


\begin{tabular}{|c|c|c|c|c|}
\hline Authors & City & Year & Accounting gas & Division \\
\hline Xing, et al. [18] & Beijing & $\begin{array}{l}1995-20 \\
05\end{array}$ & $\begin{array}{l}\text { carbon emissions from final } \\
\text { energy }\end{array}$ & Agriculture, secondary industry, tertiary consumer life \\
\hline Zhu [19] & Beijing & $\begin{array}{l}2001-20 \\
07\end{array}$ & $\mathrm{CO}_{2}$ & $\begin{array}{l}\text { agriculture, industry, buildings, transportation, commercial, residential area } \\
\text { and living, electricity and heating }\end{array}$ \\
\hline Zhang and Yang [21] & Shanghai & 2008 & $\mathrm{CO}_{2}$ from energy activities & Thermal power plants, industry, agriculture, commerce, transport, living \\
\hline Guo et al. [28] & Shanghai & $\begin{array}{l}2001-20 \\
06\end{array}$ & carbon emissions a final energy & Primary industry, secondary industry and tertiary \\
\hline Cao et al. [2] & Xiamen & 2007 & $\mathrm{CO}_{2}$ from energy activities & Industries, family, traffic, commerce \\
\hline Wang, et al. [1] & Wuxi & 2004 & $\mathrm{CO}_{2} \mathrm{CH}_{4} \mathrm{~N}_{2} \mathrm{O}$ & $\begin{array}{l}\text { industries, transportation, living, commercial, industrial processes and } \\
\text { waste disposal }\end{array}$ \\
\hline Yang, et al. [26] & Chongqing & $\begin{array}{l}1997-20 \\
03\end{array}$ & $\mathrm{CO}_{2} \mathrm{CH}_{4} \mathrm{~N}_{2} \mathrm{O}$ & $\begin{array}{l}\text { energy activities, industry, waste disposal, agriculture, animal husbandry, } \\
\text { wetlands and forestry carbon sequestration process }\end{array}$ \\
\hline Guo, et al. [29] & $\begin{array}{l}\text { Beidaihe New } \\
\text { District }\end{array}$ & 2011 & $\mathrm{CO}_{2}$ & industries (tourism, services, industry, energy, agriculture) \\
\hline GU, et al. [27] & Harbin & 2011 & $\mathrm{CO}_{2}$ & $\begin{array}{l}\text { industries, energy, living, transport, aviation, coal development, industrial } \\
\text { processes, agriculture, waste treatment, land use/land use change and } \\
\text { forestry }\end{array}$ \\
\hline Hu and Song [30] & Liu Zhou & 2013 & $\mathrm{CO}_{2}$ & energy, industries \\
\hline Jiang, et al. [35] & Beijing & 2011 & $\mathrm{CO}_{2}$ from land use & $\begin{array}{l}\text { public facilities, residential areas, industrial sites, warehouse space, } \\
\text { airports, towns, railroads, long-distance passenger transport, garden and } \\
\text { woodland, farmland, grassland farming land and fish ponds, etc. }\end{array}$ \\
\hline
\end{tabular}

Table 4: Studies on urban GHG inventory in China.

\section{GHG Inventory and $\mathrm{CO}_{2}$ Emission in Beijing}

Because Beijing is the capital city, where more data is available and more policy-makers and researchers are located, not surprisingly there have been comparatively more reports about its $\mathrm{CO}_{2}$ emission and GHG inventory.

\section{Early studies on Beijing's $\mathrm{CO}_{2}$ Emissions}

According to Cai et al. [31], from the 1980s, China has cooperated with Canada to start "Beijing's GHG Emissions Inventory Research". The preparation of the inventory mainly includes the estimation of the emission amount of three GHGs: $\mathrm{CO}_{2}, \mathrm{CH}_{4}$ and $\mathrm{N}_{2} \mathrm{O}$ from energy, industrial production, agricultural activity, land-use change and forestry, urban waste disposal. City-level GHG emission calculation is strictly prepared according to a series of principles and guidance widely accepted. Zhu [19] first calculated Beijing's carbon emissions. The thesis uses data from 2005 to analyze and finds that Beijing's GHG emissions mainly come from energy, industrial production, agriculture, land use change and forestry as well as urban waste disposal. $\mathrm{CO}_{2}$ is the most influential GHG which takes up $76.7 \%$ of the total amount. According to Zhu's research, during 1970-2007, 93.78\% of Beijing's GHG emissions originated from energy activities, among which the greatest rise came from power generation and urban heating, industry and transportation. These three industries emitted $80 \%$ of the total.

\section{GHG Inventory in Beijing}

Chinese cities exhibit many differences from western cities. Firstly, the Chinese city is an administrative body instead of an autonomous one like the Western city; the municipal government has the right of financial revenue and expenditure, while urban districts and subdistricts do not have the right. Secondly, the Chinese city is an administrative area, including urban and suburban areas. A municipality is similar to a province, consisting of urban areas, suburban areas and counties. A prefecture-level city consists of urban areas and counties, while a county-level city consists of urban areas and villages and towns, not as clearly demarcated as Western cities. Thirdly, the statistical data of the Chinese city are scattered, thus, it is difficult to count and calculate GHG emissions inventories as in Western developed countries. Some research works in 1980-90 did not use Western methodologies and therefore they are difficult to use to make international comparisons.

$\mathrm{Gu}$ and Yuan [32] present the flow chart of Chinese city-level GHG inventory and GHG emissions preparation to explain the gap between China and overseas. By the use of ICLEI2009 GHG inventory protocol, Beijing GHG inventory and data sources were consolidated (Table 5), and found that Beijing GHG inventory can only meet the comparability requirements and categories in the aggregate due to statistical differences [33]. It is difficult to achieve statistical requirements of the ICLEI protocol on two levels and three-ranges. 
Citation: Chaolin GU, Li Y, Cook IG (2014) China's Urban GHG Inventory and Emissions. J Climatol Weather Forecasting 2: 118. doi:

Page 6 of 10

\begin{tabular}{|c|c|c|c|c|c|c|c|}
\hline \multicolumn{2}{|c|}{ UNFCCC Department } & $\begin{array}{l}\text { Emission } \\
\text { Category }\end{array}$ & Data Selection & $\begin{array}{l}\text { Data } \\
\text { of Beijing in } 2007\end{array}$ & Data Format & Data Source & Assessment \\
\hline \multirow{12}{*}{ Energy } & \multirow{3}{*}{$\begin{array}{l}\text { Static } \\
\text { Source }\end{array}$} & $\begin{array}{l}\text { Fuel consumption of } \\
\text { public facility }\end{array}$ & $\begin{array}{l}\text { Fuel consumption of } \\
\text { tertiary industry }\end{array}$ & $\begin{array}{lr}\text { Total energy } \\
\text { consumption } & \text { by } \\
\text { industry and } & \text { the } \\
\text { consumption } & \text { of } \\
\text { primary } & \text { energy } \\
\text { species } & \end{array}$ & $\begin{array}{l}\text { Standard quantity } \\
\text { of different } \\
\text { energy types }\end{array}$ & $\begin{array}{ll}\text { Statistical } & \\
\text { Yearbook } & \text { of } \\
\text { Beijing } & \text { in } \\
2010 & \end{array}$ & $\begin{array}{l}\text { Power and heat } \\
\text { need to be } \\
\text { subtracted and } \\
\text { calculated in energy } \\
\text { industry }\end{array}$ \\
\hline & & $\begin{array}{l}\text { Primary industry, } \\
\text { manufacturing and } \\
\text { building industry and } \\
\text { residents' living }\end{array}$ & $\begin{array}{l}\text { Fuel consumption of } \\
\text { primary and } \\
\text { secondary industry } \\
\text { (not including energy) }\end{array}$ & $\begin{array}{lr}\text { Total energy } \\
\text { consumption } & \text { by } \\
\text { industry and } & \text { the } \\
\text { consumption } & \text { of } \\
\text { primary } & \text { energy } \\
\text { species } & \end{array}$ & $\begin{array}{l}\text { Standard quantity } \\
\text { of different } \\
\text { energy types }\end{array}$ & $\begin{array}{ll}\text { Statistical } & \\
\text { Yearbook } & \text { of } \\
\text { Beijing } & \text { in } \\
2010 & \end{array}$ & $\begin{array}{l}\text { Data needs to be } \\
\text { converted into } \\
\text { physical quantity }\end{array}$ \\
\hline & & 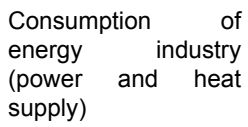 & $\begin{array}{l}\text { Energy consumption } \\
\text { of power and heat } \\
\text { supply }\end{array}$ & $\begin{array}{lr}\begin{array}{l}\text { Energy } \\
\text { sheet }\end{array} & \text { balance } \\
\text { quantity) } & \end{array}$ & $\begin{array}{l}\text { Physical quantity } \\
\text { of energy types }\end{array}$ & $\begin{array}{ll}\text { Statistical } & \\
\text { Yearbook } & \text { of } \\
\text { Beijing } & \text { in } \\
2010 & \end{array}$ & $\begin{array}{l}\text { In terms of the } \\
\text { electricity, double } \\
\text { counting should be } \\
\text { avoided }\end{array}$ \\
\hline & \multirow{7}{*}{ Transportation } & \multirow{3}{*}{$\begin{array}{l}\text { Highway } \\
\text { transportation }\end{array}$} & $\begin{array}{l}\text { Transportation, } \\
\text { storage and mail } \\
\text { business }\end{array}$ & $\begin{array}{lr}\text { Total energy } \\
\text { consumption } & \text { by } \\
\text { industry and } & \text { the } \\
\text { consumption } & \text { of } \\
\text { primary } & \text { energy } \\
\text { species } & \end{array}$ & $\begin{array}{l}\text { Physical quantity } \\
\text { of energy types }\end{array}$ & $\begin{array}{ll}\text { Statistical } & \\
\text { Yearbook } & \text { of } \\
\text { Beijing } & \text { in } \\
2010 & \end{array}$ & $\begin{array}{l}\text { Since it includes } \\
\text { storage and mail } \\
\text { business, the index } \\
\text { only acts as a } \\
\text { calibration one }\end{array}$ \\
\hline & & & $\begin{array}{l}\text { Vehicle type and } \\
\text { amount }\end{array}$ & $\begin{array}{l}\text { Amount of civil } \\
\text { vehicles }\end{array}$ & $\begin{array}{l}\text { Amount of } \\
\text { vehicles }\end{array}$ & $\begin{array}{ll}\text { Statistical } & \\
\text { Yearbook } & \text { of } \\
\text { Beijing } & \text { in } \\
2010 & \end{array}$ & $\begin{array}{l}\text { It needs to calculate } \\
\text { combined with } \\
\text { energy statistics }\end{array}$ \\
\hline & & & $\begin{array}{l}\text { Amount of public } \\
\text { tram/bus and taxis }\end{array}$ & $\begin{array}{l}\text { Public transportation } \\
\text { and passenger } \\
\text { transport taxis }\end{array}$ & $\begin{array}{l}\text { Amount } \\
\text { vehicles }\end{array}$ & $\begin{array}{l}\text { Statistical } \\
\text { Yearbook of } \\
\text { Beijing in } \\
1949 \text { to } 2010\end{array}$ & $\begin{array}{l}\text { still needs data such } \\
\text { as mileage and oil } \\
\text { consumption }\end{array}$ \\
\hline & & $\begin{array}{l}\text { Track traffic } \\
\text { (metro) }\end{array}$ & Mileage of track traffic & $\begin{array}{l}\text { Public transportation } \\
\text { and passenger } \\
\text { transport taxis }\end{array}$ & Kilometrage & $\begin{array}{l}\text { Statistical } \\
\text { Yearbook of } \\
\text { Beijing in } \\
1949 \text { to } 2010\end{array}$ & $\begin{array}{l}\text { still needs mileage } \\
\text { per day and energy } \\
\text { consumption per } \\
\text { mileage unit }\end{array}$ \\
\hline & & $\begin{array}{l}\text { Railway } \\
\text { transportation }\end{array}$ & Local Distance & Transportation line & Kilometrage & $\begin{array}{l}\text { Statistical } \\
\text { Yearbook of } \\
\text { Beijing in } \\
1949 \text { to } 2010\end{array}$ & $\begin{array}{l}\text { It is not available } \\
\text { because there is } \\
\text { only distance without } \\
\text { total mileage }\end{array}$ \\
\hline & & Air transportation & & & & & No Data \\
\hline & & $\begin{array}{l}\text { Waterway } \\
\text { transportation }\end{array}$ & - & - & - & - & $\begin{array}{l}\text { Beijing does not } \\
\text { contain waterway } \\
\text { transportation }\end{array}$ \\
\hline & \multirow{2}{*}{ Fugitive Emission } & $\begin{array}{l}\text { Coal mining process } \\
\text { and post-mine } \\
\text { activities }\end{array}$ & transportation & balance & Crude oil, natural & $\begin{array}{l}\text { Statistical } \\
\text { Yearbook }\end{array}$ & $\begin{array}{l}\text { Beijing lacks coal } \\
\text { and natural gas }\end{array}$ \\
\hline & & $\begin{array}{l}\text { Petrol and natural } \\
\text { gas mining and post- } \\
\text { mine activities }\end{array}$ & distribution loss & quantity) & gas & $\begin{array}{l}\text { Beijing in } \\
2010\end{array}$ & $\begin{array}{l}\text { loss data to replace } \\
\text { it }\end{array}$ \\
\hline \multicolumn{2}{|c|}{ Industrial Production Process } & 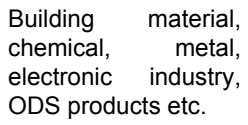 & & & & & $\begin{array}{l}\text { Need the detailed } \\
\text { data related to the } \\
\text { process of each } \\
\text { industry }\end{array}$ \\
\hline \multicolumn{2}{|c|}{ Agriculture } & stockbreeding & Amount of livestock & $\begin{array}{l}\text { Livestock breeding } \\
\text { and production }\end{array}$ & heads & $\begin{array}{ll}\text { Statistical } & \\
\text { Yearbook } & \text { of } \\
\text { Beijing } & \text { in } \\
2010 & \end{array}$ & $\begin{array}{l}\text { Mainly calculate } \\
\text { methane emission of } \\
\text { animal intestinal } \\
\text { fermentation }\end{array}$ \\
\hline
\end{tabular}


Citation: Chaolin GU, Li Y, Cook IG (2014) China's Urban GHG Inventory and Emissions. J Climatol Weather Forecasting 2: 118. doi:

Page 7 of 10

\begin{tabular}{|c|c|c|c|c|c|c|}
\hline & \multirow{2}{*}{ Crop production } & $\begin{array}{l}\text { Agricultural land and } \\
\text { arable land are }\end{array}$ & $\begin{array}{l}\text { Land area and its } \\
\text { use }\end{array}$ & $\begin{array}{l}\text { Square } \\
\text { kilometers }\end{array}$ & \begin{tabular}{ll|} 
Statistical & \\
Yearbook & of \\
Beijing & in \\
2010 &
\end{tabular} & $\begin{array}{l}\text { Within the city } \\
\text { boundary }\end{array}$ \\
\hline & & Crops area & $\begin{array}{l}\text { Crops sowing area } \\
\text { and forestation area }\end{array}$ & $\begin{array}{l}\text { Square } \\
\text { kilometers }\end{array}$ & \begin{tabular}{ll|} 
Statistical & \\
Yearbook & of \\
Beijing & in \\
2010 &
\end{tabular} & $\begin{array}{l}\text { Need the detailed } \\
\text { data of crop varieties }\end{array}$ \\
\hline \multirow{2}{*}{$\begin{array}{l}\text { Land use, land use change and } \\
\text { forestry }\end{array}$} & Land use change & $\begin{array}{l}\text { Agricultural land, } \\
\text { building land, unused } \\
\text { land change }\end{array}$ & $\begin{array}{l}\text { Land area and } \\
\text { use2006, 2007 }\end{array}$ & $\begin{array}{l}\text { Square } \\
\text { kilometers }\end{array}$ & $\begin{array}{ll}\text { Statistical } & \\
\text { Yearbook } & \text { of } \\
\text { Beijing } & \text { in } \\
2010 & \end{array}$ & $\begin{array}{l}\text { Not identical to } \\
\text { international } \\
\text { standards, lacking in } \\
\text { grassland and } \\
\text { wetland }\end{array}$ \\
\hline & $\begin{array}{l}\text { Forestry carbon } \\
\text { sequestration }\end{array}$ & $\begin{array}{l}\text { Forest area, } \\
\text { forestation area of this } \\
\text { year }\end{array}$ & $\begin{array}{l}\text { gardening, greening } \\
\text { and forest status }\end{array}$ & hectare & $\begin{array}{l}\text { Statistical } \\
\text { Yearbook of } \\
\text { Beijing in } \\
1949 \text { to } 2010\end{array}$ & $\begin{array}{l}\text { Need to use the data } \\
\text { of different years }\end{array}$ \\
\hline \multirow{4}{*}{ Waste } & Waste landfill & $\begin{array}{l}\text { Trash amount, feces } \\
\text { amount, disposal rate }\end{array}$ & Environmental health & 10 thousand tons & \begin{tabular}{ll|} 
Statistical & \\
Yearbook & of \\
Beijing & in \\
2010 &
\end{tabular} & $\begin{array}{l}\text { Amount of burning } \\
\text { and landfill }\end{array}$ \\
\hline & Waste burning & & & & & $\begin{array}{l}\text { Need to get the data } \\
\text { from municipal } \\
\text { sector }\end{array}$ \\
\hline & \multirow{2}{*}{\begin{tabular}{lc|} 
Living & sewage, \\
industrial & sewage \\
and silt disposal
\end{tabular}} & $\begin{array}{l}\text { Annual amount and } \\
\text { rate of sewage } \\
\text { disposal }\end{array}$ & $\begin{array}{l}\text { Water disposal and } \\
\text { saving }\end{array}$ & $\begin{array}{l}10 \quad \text { thousand } \\
\text { cubic meters }\end{array}$ & \begin{tabular}{ll|} 
Statistical & \\
Yearbook & of \\
Beijing & in \\
2010 &
\end{tabular} & \multirow{2}{*}{$\begin{array}{l}\text { Combine the two } \\
\text { data to obtain living } \\
\text { sewage }\end{array}$} \\
\hline & & Industrial sewage & $\begin{array}{l}\text { Environmental } \\
\text { protection }\end{array}$ & 10 thousand tons & \begin{tabular}{ll|} 
Statistical & \\
Yearbook & of \\
Beijing & in \\
2010 &
\end{tabular} & \\
\hline
\end{tabular}

Table 5: Beijing GHG Inventory Data and Assessment

\section{$\mathrm{CO}_{2}$ emission in Beijing}

According to the data of the China Energy Statistical Yearbook, based on the calculation method of IPCC, fuel net carbon values provided by IPCC and China's energy heat values were used for statistics on Beijing carbon emissions (methane and nitrous oxide equivalent values were excluded in carbon emissions). The results show that Beijing $\mathrm{CO}_{2}$ emission was about 173.0 million tons in 2011, an increase of 38.27 million tons over 2005 (Table 6).

\begin{tabular}{|l|l|}
\hline Year & $\mathrm{CO}_{2}$ emission (Million tons) \\
\hline 2005 & 134.73 \\
\hline 2007 & 153.39 \\
\hline 2008 & 151.39 \\
\hline 2009 & 158.00 \\
\hline 2011 & 173.00 \\
\hline
\end{tabular}

Table 6: Beijing $\mathrm{CO}_{2}$ emission

Beijing carbon emissions are mainly sourced from three major sectors, i.e., industry, construction and transport. On the basis of urban energy consumption survey and analysis, the calculation method of IPCC was used for statistics on Beijing urban carbon emissions [34].

Industry: The $\mathrm{CO}_{2}$ emission of the manufacturing sector accounted for $83 \%$ of the industrial total, those of power, gas, water production and supply sector accounted for $16 \%$, and that of the mining industry accounted for $1 \%$. As viewed from internal manufacturing industry, the carbon dioxide emission of three traditional manufacturing sectors accounted for $64 \%$, while that of modern manufacturing industry accounted for $14 \%$, and that of urban industry accounted for $10 \%$.

Construction: Beijing carbon emission of the construction sector was 60.533 million tons in 2009, accounting for $40 \%$ of Beijing total carbon emission, of which the residential carbon emission was 27.195 million tons, accounting for $45 \%$, and that of public buildings accounted for $55 \%$. Among various energy consumption and carbon emissions of the construction sector, the carbon emission of power was the maximum at 33.53 million tons, accounting for 55\%; followed by that of coal, heat and natural gas. The carbon emissions of these four energy consumptions accounted for $98 \%$ of total carbon emission in the construction sector. The total carbon emission of residential buildings was 27.195 million tons in 2009, of which that of urban and rural residential buildings accounted for $75 \%$ and $25 \%$ respectively.

Transportation: In 2009, the energy consumption of the transportation sector was 14.88 million tons of standard coal, and the $\mathrm{CO}_{2}$ emission was 31.22 million tons, of which the carbon dioxide 
emission of rail transit was 530,000 million tons, that caused by air energy consumption was 10.62 million tons, that of the rail sector was totaled at 3.72 million tons, and that of the road sector was approximately 3.98 million tons. Beijing per-capita motor vehicle occupation reached 0.18 automobiles/person with an annual growth rate of 0.2 automobiles/person. The passenger volume of ground bus transit was 5.17 billion in 2009 .

Based on the Beijing Statistical Yearbook 2011 of the energy, Jiang et al. [35] calculated Beijing 2011 final energy consumption as $66,950,000$ tce (tons of standard coal), $\mathrm{CO}_{2}$ emissions related was 173 million tons, per unit of GDP emission intensity $1.06 \mathrm{t} \mathrm{CO}_{2} / 10$ thousand Yuan GDP, per-capita carbon emission intensity 8.56t $\mathrm{CO}_{2} /$ person. The Beijing GHG emissions inventory included production, construction and transportation, and the three sectors accounted for $34 \%, 44 \%$ and $22 \%$ respectively. Urban land use divided into public facilities, residential areas, industrial sites, warehouse space, airports, towns, railroads, long-distance passenger transport, garden and woodland, arable land, pasture land and aquaculture ponds, etc.. All types of land use emissions of $\mathrm{CO}_{2}$ were estimated as shown in Table 7.

\begin{tabular}{|c|c|c|c|c|c|c|c|}
\hline & \multicolumn{2}{|c|}{ Energy consumption } & \multicolumn{2}{|c|}{ CO2 emissions } & \multicolumn{3}{|l|}{$\mathrm{CO} 2$ emissions from various types of land } \\
\hline & 10,000 tons & $\%$ & 10,000 tons & $\%$ & land type & 10,000 tons & $\%$ \\
\hline \multirow[t]{3}{*}{ Building } & 2762 & 41 & 7548 & 44 & & & \\
\hline & & & & & Public facilities & 4367 & 30.26 \\
\hline & & & & & Urban residential areas and villages & 3181 & 22.04 \\
\hline \multirow[t]{3}{*}{ Production } & 2194 & 33 & 5928 & 34 & & & \\
\hline & & & & & Industrial land & 4084 & 28.30 \\
\hline & & & & & Warehouse space & 1077 & 7.47 \\
\hline \multirow[t]{2}{*}{ Transportation } & 1739 & 26 & 3801 & 22 & & & \\
\hline & & & & & Airports, railways, long-distance passenger & 1455 & 10.08 \\
\hline Other & & & & & $\begin{array}{l}\text { cultivated garden and woodland, grassland } \\
\text { farming land and fish ponds, etc. }\end{array}$ & 266 & 1.85 \\
\hline Subtotal & 6695 & & 17277 & & & 14430 & \\
\hline $\begin{array}{lr}\text { Redeployment } & \text { of } \\
\text { electricity } & \text { and } \\
\text { heating } & \end{array}$ & 5997 & 39.31 & 15476 & 39.39 & & & \\
\hline $\begin{array}{l}\text { Intercity passenger } \\
\text { and freight }\end{array}$ & 2533 & 16.64 & 6535 & 16.63 & & & \\
\hline Total & 15225 & & 39288 & & & & \\
\hline
\end{tabular}

Table 7: Types of land use and $\mathrm{CO}_{2}$ emissions in Beijing (2011)

\section{Beijing $\mathrm{CO}_{2}$ Emission in 2020}

In order to explore urban energy and carbon emissions under different development scenarios, China launched a low-carbon road map. The Beijing Institute of Urban Planning also gave scenarios of Beijing urban development based on the survey and analysis of Beijing carbon emission intensity, including: (1) Basic scenario - climate change countermeasures are not carried out in the premise of economic development as the major driving factor. (2) Low-carbon scenario - achieved through national policies in the premise of national energy security, domestic environment and low carbon roadmap [34].

Based on energy consumption intensity and expected energy-saving level of various industrial sectors in 2000-2010, combined with future economic growth expectation and considerations on economic growth, total population, urban scale and energy-saving potential, the energy data in 2011 - 2020 were forecasted, and scenario analysis was carried out on the energy data for 2020. According to current energyuse data and level, $\mathrm{CO}_{2}$ emission will reach 257 million tons in 2020.

\section{Discussion and Conclusion}

The preparation of China's GHG inventory [36] needs the support of a large amount of accurate data. But now, due to the difference in statistical scope between domestic and international emissions inventory, the current research can only satisfy the comparability in the total amount and main categories, and fails to meet the statistics of two levels and three scopes in ICLEI or the Global Protocol. As introduced above, Beijing's GHG studies are mainly focused on $\mathrm{CO}_{2}$ emissions, without considering other GHGs required by the IPCC reporting. In addition, the categorization of emission sources is unique and not internationally compatible. Table 5 consolidates Beijing's data sources with IPCC and ICLEI2009 GHG inventory protocol, but the static emission in energy departments can basically meet the classification demand, and transportation data lacks the correspondence of vehicle type and fuel amount. As for the industrial production process sector, data about annual production of products such as cement or steel need to be obtained from industry associations. The data of agricultural department and land, land use change and 
forestry department is basically available, but classification of land use is not identical to that of LULUCF (land-use, land use change and forestry), lacking in grassland and wetland. Data of waste amount and sewage amount of waste department are available, but still lack the waste amount data disposed by different methods. In short, China's urban GHG inventory can only meet the comparability requirements and categories in the aggregate due to statistical differences, but it is difficult to achieve statistical requirements of the ICLEI protocol on two levels and three scopes. However, it is also very important that urban China establish a unique GHG inventory framework and methodology system that effectively addresses climate change and permits international comparisons.

\section{Acknowledgements}

The paper is developed for the first discussion forum in Tsinghua University of "Comparative urban-scale GHG inventories: Beijing and Los Angeles" funded by the American Energy Foundation in 2010. As an achievement of the Beijing Philosophy and Social Science Planning Project (11CSA003), it has received great help from Prof. Hilda Blanco and Prof. Josh Newell in China Research Institute, University of South California, U.S. The referees have also provided valuable guidance, particularly by drawing our attention to the new Global Protocol on GHG Emissions that is rapidly emerging as a new international norm in this area. This work was partially supported by the grant from Japan Society for the Promotion of Science (KAKENHI No.26420634).

\section{References}

1. Wang K, Zhang R, Bi J (2011) China's urban carbon emissions accounting research: Case Study of Wuxi. China Environmental Science 31: 1029-1038.

2. Cao B, Lin J, Cui S et al. (2010) Analysis scenarios of Xiamen saving energy and greenhouse gas reduction based on LEAP. Acta Ecologica Sinica 30: 3358-3367.

3. GRIP (2012) The Greenhouse Gas Regional Inventory Protocol. (http:// www.getagriponemissions.com/history.html accessed March 20th 2013).

4. Guideline Editing Team of provincial-level greenhouse gas inventory (2010) Provincial guidelines for the preparation of greenhouse gas inventories (Trial). Beijing: National Development and Reform Commission

5. The greenhouse gas protocol: a corporate accounting and reporting standard, revised edition (2004) World Resources Institute (WRI)/World Business Council for Sustainable Development (WBCSD), WRI/WBCSD, Washington DC, USA.

6. ISO 14064(2006) (http://www.iso.org/iso/home/store/catalogue_tc/ catalogue_detail.htm?csnumber=38381accessed June 26th 2009)

7. IPCC (2006) IPCC Guidelines for National Greenhouse Gas Inventories; Intergovernmental Panel on Climate Change: Bracknell, U.K., 2006; http://www.ipcc-nggip.iges.or.jp/public/ 2006gl/index.htm (accessed September 17th, 2007).

8. Ramaswami A, Hillman T, Janson B, Reiner M, Thomas G (2008) A Demand-Centered, Hybrid Life-Cycle Methodology for City-Scale Greenhouse Gas Inventories. Environmental Science \& Technology 42: 6455-6461.

9. Kennedy CA, Ramaswami A, Carney S, Dhakal S (2011) Greenhouse Gas Emission Baselines for Global Cities and Metropolitan Regions. Hoornweg, et al (ed), Cities and Climate Change: Responding to an Urgent Agenda. The World Bank, Washington, D.C.

10. ICLEI (2012) Global Protocol For Community-Scale Greenhouse Gas Emissions (GPC) http://www.ghgprotocol.org/files/ghgp/ GPC_PilotVersion_1.0_May2012_20120514.pdf (accessed September 30th 2013)
11. Lin Z, (1999) Handbook of Preparation of China's Greenhouse Gas Emissions inventory, Beijing: China Petroleum and Chemistry Press.

12. Geng Y, Tian M, Zhub Q, Zhang J, Peng C (2011) Quantification of provincial-level carbon emissions from energy consumption in China. Renewable and Sustainable Energy Reviews 15: 3658-3668.

13. Wang W, Zheng G (2013) Annual Report on Actions to Address Climate Changes (2013): Focus on Low-Carbon Urbanization”. Beijing: Social Sciences Academic Press.

14. Zhu L, Guan D, Crawford-Brown D, Zhang Q, He K et al. (2013) Energy policy: A low-carbon road map for China. Nature 500: 143-145.

15. Davis, SJ, Caldeira K, Matthews HD (2010) Future CO2 Emissions and Climate Change from Existing Energy Infrastructure. Science 329: 1330-1333.

16. IEA (International Energy Agency) (2009) CO2 Emission from Fuel Combustion. (http://www.oecd-ilibrary.org/energy/data/iea-co2emissions-from-fuel-combustion-statistics_co2-data-en accessed February 3rd 2010)

17. He J, Deng J, Su M (2009) CO2 emission from China's energy sector and strategy for its control. Energy 35: 4494-4498.

18. Xing FF, Ouyang ZY, Wang XK, Duan XN, Zheng H et al. (2007) Inventory of final energy-carbon consumption and its structure in Beijing. Huan Jing Ke Xue 28: 1918-1923.

19. Zhu S (2009) Research on Current Situations of Beijing's Greenhouse Gas Emissions and Emission Reduction Countermeasures. China Soft Science 93-106.

20. Chen C, Liu C, Tian G (2010) Progress in research of urban greenhouse gas emission inventories. Environmental Science 31: 2780-2787.

21. Zhang W, Yang Y (2010) Urban energy consumption and carbon dioxide emissions accounting inventory: case studies of Shanghai. Urban Management and Technology 17-21.

22. Zhao Q (2011) Shanghai greenhouse gas inventory. Fudan University PhD Dissertation.

23. Geng Y (2011) Energy use and CO2 Emission Invertories in the Four Municipalities of China. Energy Procedia 5: 370-376.

24. Xu S (2011) Nanjing's greenhouse gas emissions and its spatial distribution. University PhD Dissertation.

25. Li Z, Zhi G, Wei X (2011) Preliminary research on Kunming industrial carbon emissions. Environmental Science Survey 30: 10-14.

26. Yang J, Ju L, Chen B (2012) Greenhouse Gas Inventory and Emission of Chongqing, China Population. Resources and Environment 22: 63-69.

27. Gu C, Liu W, Guo J, Yu Y et al. (2012) Low-carbon-oriented master plan of Harbin. In: Chinese Society for Urban Studies (ed.), China Lowcarbon Eco-city Development Report 2012. Beijing: China Construction Press, pp: 213-218.

28. Guo Y, Zhao Y, Lin F et al. (2010) Study of variation of the carbon emissions of final energy use: case of Shanghai. Environmental Science and Technology 33: 88-92.

29. Guo J, Gu C, Yang B, Yi X (2012) Industrial Carbon Emission Inventory of Qinghuangdao (Beidaihe New Town). In: Chinese Society for Urban Studies (ed.), China Low-carbon Eco-city Development Report 2012. Beijing: China Construction Press, pp: 209-213.

30. $\mathrm{Hu}$ W, Song S (2013Industry Carbon Dioxide Emissions in Liuzhou Region. Journal of Ningbo University (NSEE) 26: 107-110.

31. Cai B, Liu C, Chen C, et al. (2009) Research on Urban Greenhouse Gas Inventory. Beijing: Chemical Industry Press.

32. Gu C, Yuan X (2011) Urban Greenhouse Gas Inventory and Methods in China. Urban Environment Urban Ecology 24: 1-4.

33. Yuan X, Gu C (2011) Urban Greenhouse Gas Inventory and Methods in Beijing. Urban Environment Urban Ecology 24: 5-8.

34. He Y (2012) CO2 Emission and Carbon Sinks. In: Chinese Society for Urban Studies (ed.), China Low-carbon Eco-city Development Report 2012. Beijing: China Construction Press, pp: 197-209.

35. Jiang Y, He Y, Mao Q, Chen S, He D (2013) City-level Greenhouse Gas Emission Inventory from a Spatial Planning Perspective. City Planning Review 37: 50-56. 
Citation: Chaolin GU, Li Y, Cook IG (2014) China's Urban GHG Inventory and Emissions. J Climatol Weather Forecasting 2: 118. doi: $10.4172 / 2332-2594.1000118$

Page 10 of 10

36. Bai W (2013) Framework and Content of Municipal GHG Inventory Research in China, In: Wang W, Zheng G (eds.), Annual Report on
Actions to Address Climate Changes: Focus on Low-Carbon Urbanization. Beijing: Social Sciences Academic Press, pp: 163-173. 